\title{
Uncertainty Handling in Ship Assessment: A Case Study of Bangladesh
}

\author{
Muhammed Jamshed Alam Patwary ${ }^{1}$, Mohammad Osiur Rahman ${ }^{2, ~ *, ~}$ \\ Mohammad Shahadat Hossain ${ }^{2}$ \\ ${ }^{1}$ Department of Computer Science and Engineering, International Islamic University Chittagong, Chittagong, Bangladesh \\ ${ }^{2}$ Department of Computer Science and Engineering, University of Chittagong, Chittagong, Bangladesh
}

\section{Email address:}

jap_cse@iiuc.ac.bd (M. J. A. Patwary), osiur.ukm@gmail.com (M. O. Rahman), hossain_ms@cu.ac.bd (M. S. Hossain)

\section{To cite this article:}

Muhammed Jamshed Alam Patwary, Mohammad Osiur Rahman, Mohammad Shahadat Hossain. Uncertainty Handling in Ship Assessment: A Case Study of Bangladesh. Journal of Investment and Management. Vol. 4, No. 5, 2015, pp. 152-161. doi: 10.11648/j.jim.20150405.13

\begin{abstract}
Shipping is the oldest and internationally recognized industry. It helps many national and international businesses by transporting vast amount of goods from one place to another. Most of the businesses in Bangladesh are depended on sea ports. For this reason, shipping services are very important in Bangladesh. To maximize the profit from a ship oriented business, it is essential to select the right ship for intended purpose. However, ship selection is a very critical process, because it requires handling of both qualitative and quantitative information under uncertainty. While evaluating the quality of a ship in Bangladesh, particularly in Chittagong and Mongla sea port, only quantitative parameters are considered. Qualitative and uncertain data are ignored. Sometimes it causes not to select the right ship, as a result, serious losses in businesses. The goal of this study is to overcome the existing limitations of ship selection through handling of both qualitative and quantitative data under uncertainty. In this article, evidential reasoning (ER) approach is used for aggregating both qualitative and quantitative data under uncertainly for ranking among the alternatives and finally selecting the best ship out of many alternatives. The proposed method is applied on five alternative ships of Western Fishers Shipyard Ltd (WFSL). Using the method it has been possible to rank among alternatives successfully and both qualitative and quantitative data have been collated to handle uncertainty in ship selection. It is recommended to use the ER method in ship selection, because it can handle uncertainty and helps businessmen to get maximum benefit from their businesses through selecting the best ship.
\end{abstract}

Keywords: Evidential Reasoning (ER), Uncertainty, Ship Assessment, Qualitative and Quantitative Data

\section{Introduction}

International shipping industry helps over 90 percent of world trade. It helps export and import of goods from one place to another. Seaborne trade continues to expand day by day as its demand is increasing. There are around 50,000 merchant ships trading internationally, and they transport every kind of cargo. For this reason, shipping services are very important for maritime world. It is a common and frequent event in the maritime industry to familiarize new trends and capacities of a ship, as the industry and the demand for new ship is increasing day by day. Now, choosing or deciding the best ship out of many alternatives is a big challenge faced by the decision makers. The assessment of the quality of ships is cruial since it requires many complex decisions to make as well as linear and nonliear information to be considered. Consequently, a large number of criteria of both qualitative and quantitative types are to be simultaneously measured and evaluated. From a shipbuilder's perspective the detailed design process [1] of a ship consists of the following steps:

- Market analysis is required to determining the transport demand.

- In the concept design stage, logical model of ship is designed.

- With the help of computer modeling different alternative ships are designed technically.

- Some economic criteria such as first cost, operating cost and income of different alternative ships are estimated and assessed.

- Using computer program or comparing economic criteria of alternatives optimal option is selected.

Once the design process of different alternatives is completed, they need to be compared to determine the best 
one among them. To determine the best one, the entire ship need not be compared rather some of the criteria are compared, for example, designs with higher net present value (NPV) is better than that of lower one and in the same way, lower required freight rate (RFR) is better than that of higher one. Taking risk factor into account different alternatives can be compared [2]. The total ship readiness assessment (TSRA) is used to assess the material condition of any operating ship. Comparison among alternatives is possible using TSRA.

To assess the economic and technical performance of alternative ships, ship designer requires adequate information. Economic performance evaluation is easier than technical performance evaluation because in economic performance evaluation criteria are linearly related. The success of comparing alternative ship designs depends on huge number of practical data and the use of appropriate economic analysis method. Sometimes it is difficult to have sufficient data.

The shipbuilding industry of Bangladesh has a long history. The industry is based on building simple boats and sea vessels. Many countries around the world bought ships from Bangladesh. Bangladesh has become the most prominent shipbuilding country because it has more than 200 rivers from small sizes to big sizes with a total length of around $22155 \mathrm{~km}$. Once the design and building of different ships is completed, they are required to compare to determine the best ship and rank [3], [4] among them, so that decision makers can take their decision to buy their intended ship. To compare among different alternative ships, both qualitative and quantitative criteria need to be considered [5].

The main limitation of evaluating a ship in Bangladesh is that, decision makers usually consider only quantitative criteria, in addition, they take a very few criteria into account. However, the evaluation methods do not consider any qualitative parameters and hence, the existing methods are insufficient to handle uncertainty [6] which is considered as a challenge by many researchers [7] - [16].

The proposed evidential reasoning (ER) approach [3], [17] is very different from most conventional multi-attribute decision making modeling methods. The ER approach employs a belief structure to represent a measurement as a distribution [6], [17]-[19] and aggregates nonlinear information. It aggregates distributed assessment results from lower level to higher level attributes. The ER approach uses evidential reasoning algorithm, developed on the basis of decision theory and the evidence combination rule [20] of Dempster-Shafer theory [21] to aggregate belief degrees. In the ER system both quantitative and qualitative criteria are considered and aggregated simultaneously [3], [4], [18], [19]. As a result, the uncertainty [6], [14], [18], [22]-[24] issues are resolved. The decision-makers will be able to take appropriate decision during purchasing of a ship in a short span of time because most of the significant criteria, both qualitative and quantitative are considered.

In the rest of the article, section 2 introduces the life cycle of a ship; section 3 describes the ER based ship assessment algorithm; section 4 discusses on the experimental results; and finally, describes the concluding remarks in section 5 .

\section{Life Cycle of a Ship}

The life time of a modern ship is about $25-30$ years. Figure 1 illustrates the different steps of life cycle of a modern ship. The life cycle consists of initial planning, ordering, ship building, ship operation, ship assessment and ship recycling. The article especially emphasized on the ship assessment under uncertainty.

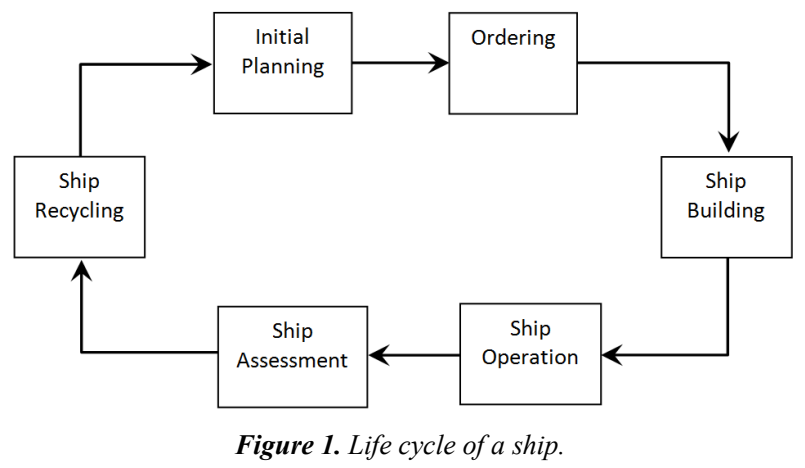

\subsection{Initial Planning}

During this step, ship owner will contact with naval architects for planning a new ship design. To design a new ship, typically earlier designs are considered as well as the state-of-the-art technology is also included.

\subsection{Ordering}

Ordering of a ship needs to communicate among ship owner, ship yard and ship broker. Once they have agreed on their conditions then ordering is occurred.

\subsection{Ship Building}

All actions such as signing of contract, production design, material and equipment purchase, production plan, steel cutting, assembly and mounting of ship sections, launching, finishing of the ship, sea trial, delivery and warranty, are done at ship building stage.

\subsection{Ship Operation}

After building the ship now it is prepared for operation.

\subsection{Ship Assessment}

The quality of the ship is evaluated at this stage, which helps to rank among various alternative ships.

\subsection{Ship Recycling}

During recycling stage of the life cycle of a ship, ship owners sell the ship for recycling to ship-breaking yard.

\section{Proposed ER Based Ship Assessment System}

The ER based ship assessment approach considered both quantitative and qualitative parameters for ship assessment 
and ranking. The overall assessment of ships evaluated based on performance, equipment, appearance, automation and economy. The evaluation hierarchy [4], [6], [19] for ship assessment is shown in Figure 2 and the block diagram of the ER based ship assessment algorithm is shown in Figure 3.

In the evaluation hierarchy, the overall ship assessment is obtained from the fusion of performance, equipment, appearance, automation and economy. The performance is evaluated based on safety, fire protection, and seaworthiness; the equipment consists of living facilities, cargo systems, anchor facilities, and communication; the appearance quality is evaluated based on waterline and internal arrangement; the parameters for automation are engine room, navigation and cargo monitor; and the net present value and required fright rate are considered to calculate the economy condition.

The main objective of this ER based ship assessment algorithm is ranking among alternative ships and it involves the following steps which are also illustrated in Figure 3.

Step 1. Representation of definition of multi-attribute decision problem

Step 2. Basic probability assignments for each basic attribute

Step 3. Combined probability assignments for a general attribute

Step 4. Combined degrees of belief for a general attribute

Step 5. Expected utility is measured

Step 6. Utility interval

Step 7. Ranking of the options

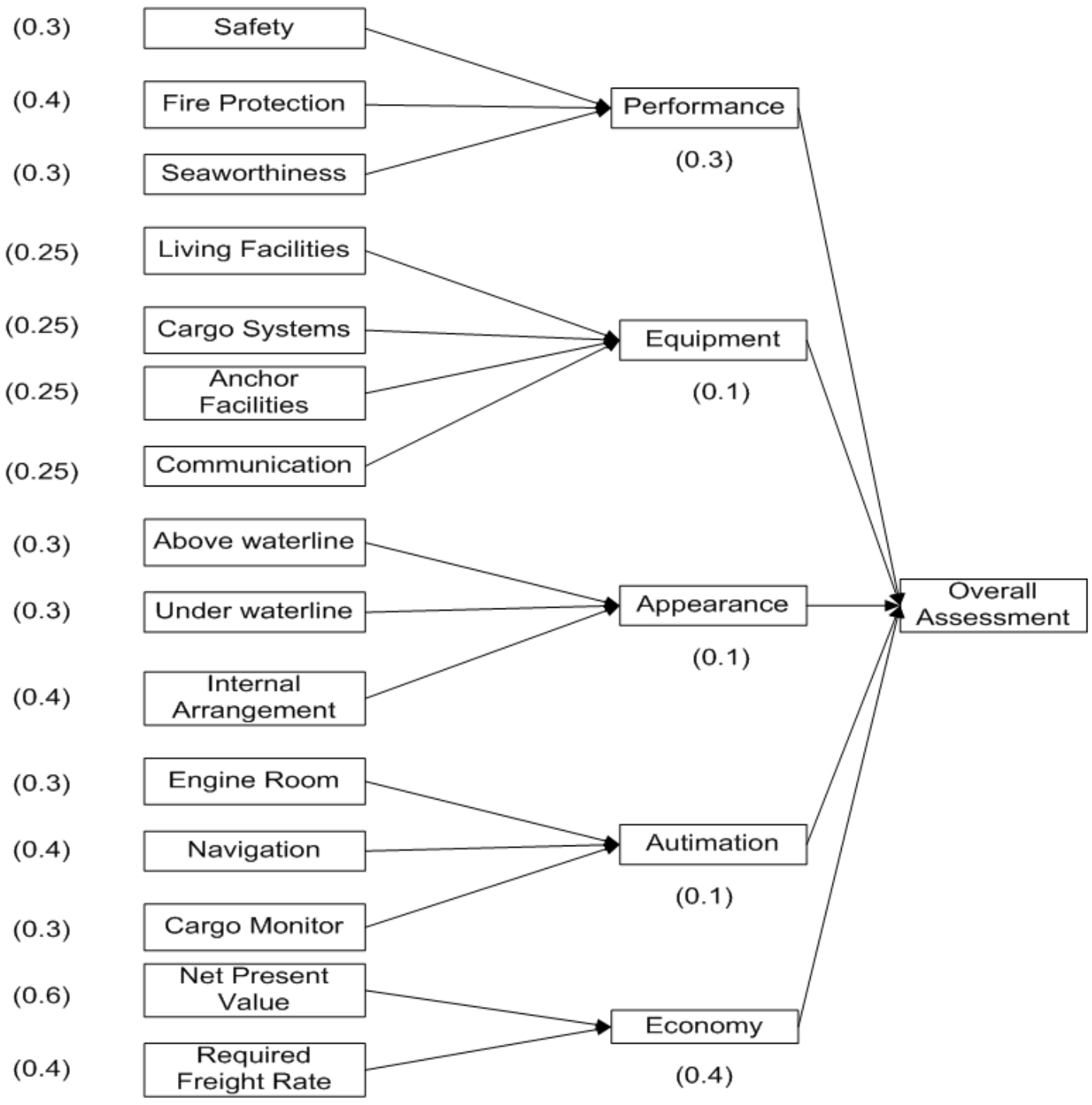

Figure 2. Evaluation Hierarchy for Ship Assessment.

\subsection{The Detailed Description of ER Based Ship Assessment Algorithm}

Suppose an aggregated attribute $x$ is calculated, taking some basic attributes into account, in a two level evaluation hierarchy [3], [5], [25]. Assume there are $P$ basic attributes. $a_{i}(i=1, \ldots, P)$. Here are computational steps of ER approach that are used to aggregate nonlinear information.

Step 1. Representation of definition of multi-attribute decision problem: A multi-attribute decision problem [26], [27], [28], [25].

a) Definition of a set of $\mathrm{P}$ basic attributes $a_{i}$ according to the following equation: 


$$
A=\left\{a_{1}, a_{2}, a_{3}, \ldots \ldots \ldots . . . a_{i}, \ldots . . a_{P}\right\}
$$

b) Estimation of the relative weights of the $\mathrm{P}$ basic attributes $w=\left\{w_{1}, w_{2}, w_{3}, \ldots \ldots \ldots . w_{i}, \ldots . . w_{P}\right\}$ where $w_{i}$ is the relative weight for basic attribute $i$ and satisfied the following equations:

$0 \leq w_{i} \leq 1$ and

$$
\sum_{i=1}^{P} w_{i}=1
$$

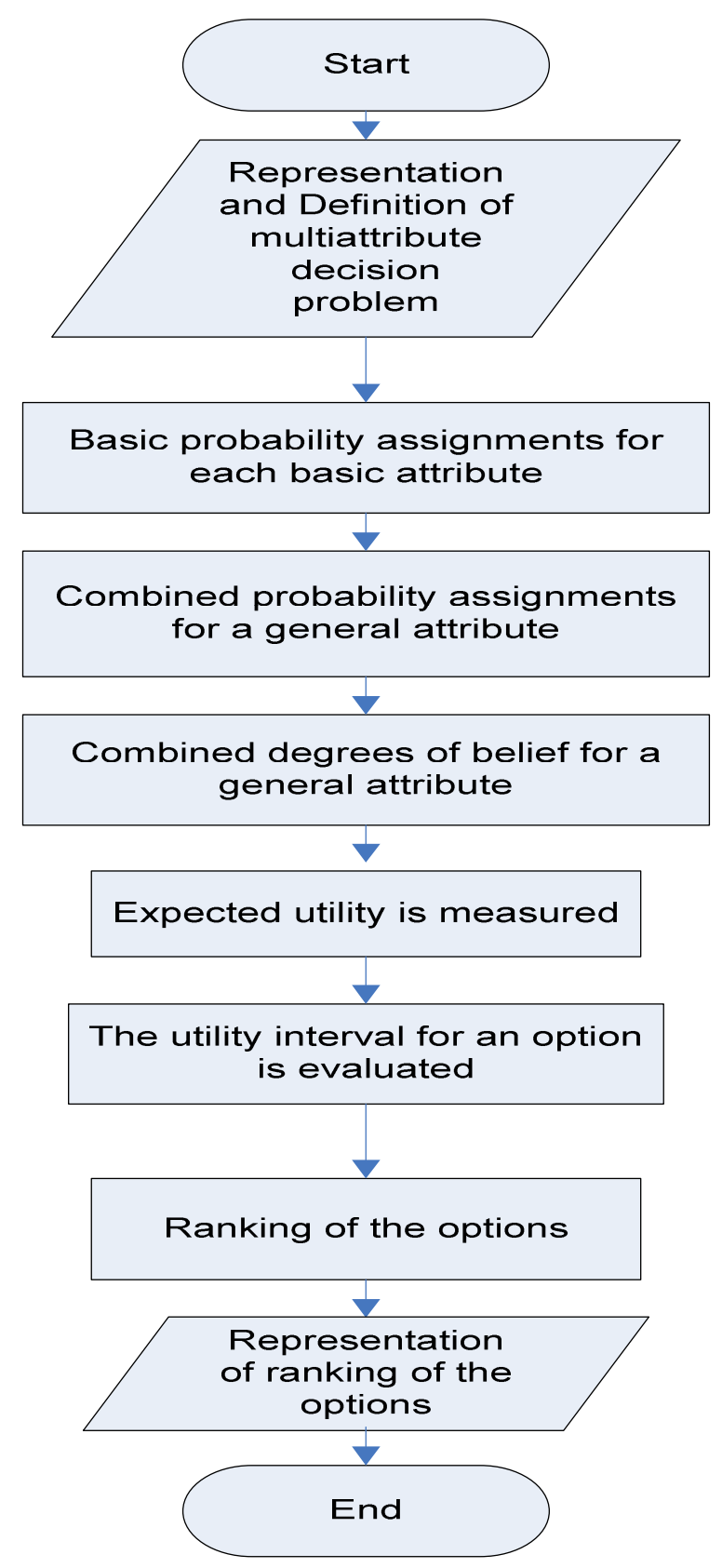

Figure 3. ER based ship assessment algorithm.

c) Definition of $Q$ different evaluation grades $H_{n}(n=1, \ldots, Q)$. as a complete set of standards for assessing each alternative option on all attributes,

$$
H=\left\{H_{1}, H_{2}, H_{3} \ldots, . H_{n} \ldots . H_{Q}\right\}
$$

d) Now, a multi-attribute decision problem can be represented using the following distributions for an option option $(l=1, \ldots, R)$ on an attribute $a_{i}(i=1, \ldots, P)$ :

$$
S\left(a_{i}\left(\text { option }_{l}\right)\right)=\left\{\left(H_{n}, \beta_{n, i}\left(\text { option }_{l}\right)\right), n=1, \ldots, Q\right\} i=1, \ldots P, l=1, \ldots, R
$$

Where, $\beta_{n, i}\left(\right.$ option $\left._{l}\right)$ indicates a degree of belief and $\beta_{n, i}\left(\right.$ option $\left._{l}\right) \geq 0$ with $\sum_{n=1}^{Q} \beta_{n, i}\left(\right.$ option $\left._{l}\right) \leq 1$. A distribution, as shown in equation (4), reads that an attribute $a_{i}$ at an option option $_{l}$ is assessed to a grade $H_{n}$ with a degree of belief $\beta_{n, i}\left(\right.$ option $\left._{l}\right)(n=1, \ldots, Q)$.

Step 2. Basic probability assignments for each basic attribute: Calculation of basic probability assignments for each basic attribute at an option, option ${ }_{l}$ Suppose $m_{n, i}$ be a basic probability mass representing the degree to which the $i$ th basic attribute $a_{i}$ supports a hypothesis that the aggregated attribute $\mathrm{x}$ at option $_{l}$ is assessed to the nth evaluation grade $H_{n}$. Suppose $m_{H, i}$ be a remaining probability mass unassigned to any individual grade after $a_{i}$ has been assessed. $m_{n, i}$ and $m_{H, i}$ are calculated as follows:

FOR i $:=1$ to $\mathrm{P}$ do

FOR $n:=1$ to $\mathrm{Q}$ do

$$
m_{n, i}=w_{i} \beta_{n, i}\left(\text { option }_{l}\right)
$$

\section{ENDFOR}

ENDFOR

FOR $i:=1$ to $P$ do

FOR $n:=1$ to $\mathrm{Q}$ do

$$
m_{H, i}=1-m_{n, i}=1-w_{i} \beta_{n, i}\left(\text { option }_{l}\right)
$$

\section{ENDFOR}

ENDFOR

Decomposition of $m_{H, i}$ into $\bar{m}_{H, i}$ and $\tilde{m}_{H, i}$

FOR i $:=1$ to $\mathrm{P}$ do

FOR $n:=1$ to $\mathrm{Q}$ do

$$
\bar{m}_{H, i}=1-w_{i} \text { and } \tilde{m}_{H, i}=w_{i}\left(1-\beta_{n, i}\right)
$$

\section{ENDFOR}

ENDFOR

With $m_{H, i}=\bar{m}_{H, i}+\widetilde{m}_{H, i}$.

Step 3. Combined probability assignments for a general attribute: Calculation of combined probability assignments for a general attribute $\mathrm{x}$ at an option option $_{l}$.

Suppose, $\quad m_{n, I(1)}=m_{n, 1}(n=1, \ldots, Q), \quad \bar{m}_{H, I(1)}=\bar{m}_{H, 1} \quad$, 
$\tilde{m}_{H, I(1)}=\tilde{m}_{H, 1} \quad$ and $\quad m_{H, I(1)}=m_{H, 1} . \quad$ The combined probability assignments $m_{n, I(P)}(n=1, \ldots, Q), \bar{m}_{H, I(P)}$, $\tilde{m}_{H, I(P)}$ and $m_{H, I(1)}$ can be calculated by aggregating all the basic probability assignments using the following recursive ER algorithm:

FOR $i:=1$ to $P$ do

FOR $n:=1$ to $\mathrm{Q}$ do

$$
\begin{gathered}
\left\{H_{n}\right\}: \\
m_{n, I(i+1)}=Z_{I(i+1)}\left[m_{n, I(i)} m_{n, i+1}+m_{n, I(i)} m_{H, i+1}+m_{H, I(i)} m_{n, i+1}\right] \\
m_{H, I(i)}=\overline{m_{H, I(i)}}+\tilde{m}_{H, I(i),} n=1, \ldots \ldots \ldots \ldots ., Q, \\
\{H\}: \\
m_{H, I(i)}=\overline{m_{H, I(i)}}+\tilde{m}_{H, I(i),} n=1 \ldots \ldots \ldots \ldots . . ., Q \\
\tilde{m}_{H, I(i+1)}=Z_{I(i+1)}\left[\tilde{m}_{H, I(i)} \tilde{m}_{H, i+1}+\tilde{m}_{H, I(i)} \bar{m}_{H, i+1}+\bar{m}_{H, I(i)} \tilde{m}_{H, i+1}\right] \\
\bar{m}_{H, I(i+1)}=Z_{I(i+1)}\left[\bar{m}_{H, I(i)} \bar{m}_{H, i+1}\right]
\end{gathered}
$$

\section{ENDFOR}

ENDFOR

Where $Z_{I, I(i+1)}$ is a normalization factor, used to resolve the conflict and this can be calculated as follows

$$
\text { if }(j \neq t)
$$

FOR $\mathrm{i}:=1$ to $\mathrm{P}-1$ do

FOR $\mathrm{j}:=1$ to $\mathrm{Q}$ do

FOR $\mathrm{t}:=1$ to $\mathrm{Q}$ do

$$
Z_{I(i+1)}=\left[1-m_{n, I(i)} m_{t, i+1}\right]^{-1}
$$

\section{ENDFOR}

ENDFOR

\section{ENDFOR}

Step 4. Combined degrees of belief for a general attribute: Combined degrees of belief for an aggregated attribute $\mathrm{x}$ at an option option are calculated with the help of following equations:

$$
\begin{aligned}
& \left\{H_{n}\right\}: \beta_{n}=\frac{m_{n, I(P)}}{1-\overline{m_{H, I(P)}}}, n=1, \ldots \ldots \ldots . . Q \\
& \{H\}: \beta_{H}=\frac{\tilde{m}_{H, I(P)}}{1-\overline{m_{H, I(P)}}}, \text { Where } m_{n, I(1)}=m_{n, 1}(n=1, \ldots . . Q)
\end{aligned}
$$

Where $\beta_{n}$ and $\beta_{H}$ represent the belief degrees of the aggregated assessment, to which the general factor (such as "facilities") is assessed to the grade $H_{n}$ and $\mathrm{H}$, respectively.

Step 5. Expected utility is measured: The distributed overall assessment of the option $a_{l}$ is given by the following equation:

$$
S\left(x\left(\text { option }_{l}\right)\right)=\left\{\left(H_{n}, \beta_{n}\left(\text { option }_{l}\right)\right), n=1, \ldots \ldots, Q\right\}
$$

Where the utility of a grade $H_{n}$, is denoted by $u\left(H_{n}\right)$.

If the overall assessment is complete, the expected utility of option ${ }_{l}$ on $\mathrm{x}$ is then calculated by the following equation:

$$
u\left(\text { option }_{l}\right)=\sum_{n=1}^{Q} \beta_{n}\left(\text { option }_{l}\right) u\left(H_{n}\right)
$$

Step 6. Utility interval: Utility interval for an option is calculated in this step. The maximum, minimum and average utilities of $a_{l}$ can be calculated by:

$$
\begin{gathered}
\left.u_{\max }\left(\text { option }_{l}\right)=\sum_{n=1}^{Q-1} \beta_{n}\left(\text { option }_{l}\right) u\left(H_{n}\right)+\left(\beta_{N}\left(\text { option }_{l}\right)+\beta_{H}\left(\text { option }_{l}\right)\right) u\left(H_{Q}\right)\right) \\
u_{\min }\left(\text { option }_{l}\right)=\left(\beta_{1}\left(\text { option }_{l}\right)+\beta_{H}\left(\text { option }_{l}\right)\right) u\left(H_{1}\right)+\sum_{n=2}^{Q} \beta_{n}\left(\text { option }_{l}\right) u\left(H_{n}\right) \\
u_{\text {average }}\left(\text { option }_{l}\right)=\frac{u_{\max }\left(\text { option }_{l}\right)+u_{\min }\left(\text { option }_{l}\right)}{2}
\end{gathered}
$$

Step 7. Ranking of the options: The ranking of two alternatives option ${ }_{l}$ and option $_{k}$ is based on their utility intervals, option ${ }_{l}$ is said to be preferred to option ${ }_{k}$ if and only

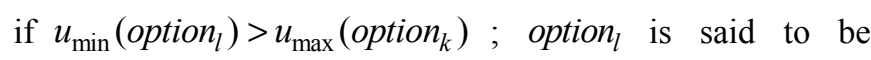
indifferent to option $_{k}$ if and only if $u_{\min }\left(\right.$ option $\left._{l}\right)=u_{\max }\left(\right.$ option $\left._{k}\right) \quad ; \quad$ and $u_{\text {max }}\left(\right.$ option $\left._{l}\right)=u_{\text {max }}\left(\right.$ option $\left._{k}\right)$. Otherwise, the average utility may be used to generate the ranking.

\subsection{Transformation from Quantitative Attribute to Qualitative Assessment}

To assess the overall performance of a ship we need to consider both qualitative data and quantitative data. These quantitative data must be converted to its equivalent qualitative assessment [4] so that, we can aggregate all data together with the help of ER algorithm. In order to transform a quantitative attribute [19], [29], [30] to a qualitative attribute the following equations are used.

$$
S\left(a_{i}(v)\right)=\left\{\left(v_{n, i}, \beta_{n, i}\right), n=1, \ldots, Q\right\}
$$

If $v_{Q, i}$ and $v_{1, i}$ are the highest and lowest quantitative values respectively of any criteria or sub-criteria, then the value $v_{n, i}$ can be evaluated to an evaluation grade $H_{n}, n=1, \ldots, Q$. Now the value $\mathrm{v}$ is associated on the attribute $a_{i}$ to the degrees of belief $\beta_{n, i}$ can be calculated with the help of above equation. Again $\beta_{n, i}$ and $\beta_{n+1, i}$ can be calculated as follows: 


$$
\beta_{n, i}=\frac{v_{n+1, i}-v}{v_{n+1, i}-v_{n, i}}, \beta_{n+1, i}=1-\beta_{n, i} \text { if } \quad v_{n, i} \leq v \leq v_{n+1, i}
$$

and $n=1, \ldots$, Q-1

$$
\beta_{k, i}=0, \text { Where } \mathrm{k}=1, \ldots, \mathrm{Q} \text { and } k \neq n, n+1
$$

\subsection{Evaluation of Economic or Quantitative Criteria}

The most important economic criteria can be summarized as follows:

i. Net Present Value (NPV):

$\mathrm{NPV}=\sum_{1}^{N}[P W($ annualc $\arg$ oquality $*$ freightrate $)-P W($ ammualoperating $\cos t s)-P W($ shipacquisition $\cos t s)]$

Where, Present Worth Factor $(\mathrm{PW})=\frac{P}{F} ; \mathrm{P}=$ Principal (investment), or a present sum of money and $\mathrm{F}=$ Future sum of money.

If the cash flows are uniform over the ship's life cycle, and the ship is paid for in a single installment, Series Present Worth (SPW) factors may be used:

Where, SPW $=\frac{P}{A} ; \mathrm{P}=$ Principal (investment), or a present sum of money and $\mathrm{A}=$ Annual return (i.e. income minus expenditure).

$$
\begin{array}{r}
\mathrm{NPV}=\mathrm{SPW} \text { (annual cargo quality } * \text { freight rate }- \text { operating } \\
\text { costs) }- \text { ship first cost }
\end{array}
$$

The design with the highest NPVs is good.

ii. Required Freight Rate (RFR)

If the ship's attainment cost, the required rate of return, all the in service costs, and the yearly transported freight quantities are known, the Required Freight Rate (RFR) [1].

] is calculated using the following equation:

$\mathrm{RFR}=\sum_{1}^{N} \frac{P W(\text { annualoperaing } \cos t s)+(P W(\text { shipacquisition } \cos t))}{\text { annualc } \arg \text { oquality }}$

For uniform cash flows a useful simplification is possible:

$\mathrm{RFR}=\frac{\text { annualoperating } \cos t s+C R(\text { shipfirst } \cos t)}{\text { annualc } \arg \text { otonnage }}$

Where, Capital Recovery Factor $(\mathrm{CR})=\frac{1}{S P W}$.

The design with the lowest RFR is best.

iii. Yield or DCF Rate of Return.

If the freight income in known, the yield also called Discounted Cash Flow Rate of Return can be calculated [1].Yield we can compare among widely different alternatives, particularly when funds available for investment are comparatively clear.

\subsection{Performance Evaluation}

The distributed overall assessment of the option option ${ }_{l}$ is given by the following equation:
The present worth of each item of income and expenditure is determined if the ship's attainment cost, the required rate of return on the capital invested, the operating costs of ship each year, the transported cargo amount each year and the corresponding freight rate of a ship are known. Then these items can be summed up to find the Net Present Value (NPV) [1].

The general formula for calculating NPV is:

$$
S\left(x\left(\text { option }_{l}\right)\right)=\left\{\left(H_{n}, \beta_{n}\left(\text { option }_{l}\right)\right), n=1, \ldots \ldots, Q\right\} .
$$

If the overall assessment is complete, the expected utility of option , on $\mathrm{x}$ is then calculated by

$$
u\left(\text { option }_{l}\right)=\sum_{n=1}^{Q} \beta_{n}\left(\text { option }_{l}\right) u\left(H_{n}\right)
$$

Where the utility of a grade $H_{n}$, is denoted by $u\left(H_{n}\right)$.

The maximum, minimum and average utilities of option ${ }_{l}$ can be calculated by:

$$
\begin{gathered}
\left.u_{\max }\left(\text { option }_{l}\right)=\sum_{n=1}^{Q-1} \beta_{n}\left(\text { option }_{l}\right) u\left(H_{n}\right)+\left(\beta_{Q}\left(\text { option }_{l}\right)+\beta_{H}\left(\text { option }_{l}\right)\right) u\left(H_{Q}\right)\right) \\
u_{\min }\left(\text { option }_{l}\right)=\left(\beta_{1}\left(\text { option }_{l}\right)+\beta_{H}\left(\text { option }_{l}\right)\right) u\left(H_{1}\right)+\sum_{n=2}^{Q} \beta_{n}\left(\text { option }_{l}\right) u\left(H_{n}\right) \\
u_{\text {average }}\left(\text { option }_{l}\right)=\frac{u_{\max }\left(\text { option }_{l}\right)+u_{\min }\left(\text { option }_{l}\right)}{2}
\end{gathered}
$$

\subsection{Implementation of ER Algorithm in Ship Assessment}

The proposed system represented in this paper uses ER algorithm in the assessment and ranking of ships with some common criteria. Different steps of ER algorithm are implemented by the equations, stated in the earlier section of this paper. The architectural design of the system is presented to expose the overall implementation of the computer based system in figure- 4 .

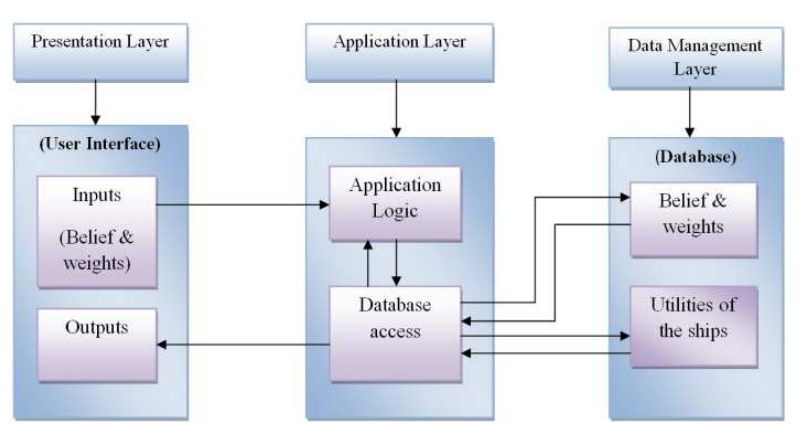

Figure 4. Architectural Design of the System. 
The Architecture of the system consists of three layerspresentation layer, application processing layer and data management layer [31]. The presentation layer consisting of two basic parts of the system (inputs and outputs) provides the interface for the users while the application layer conceivers all application logics. An adequate environment to access database is also assured in this layer. The data management layer maintains the database of the system.

\section{Experimental Results}

The ER based ship assessment algorithm is implemented using Turbo $\mathrm{C}$ version 3.0 and the graphical block diagrams are drawn using Microsoft Office Visio 2003. The real raw data are collected from Western Fishers Shipyard Ltd, a renowned company of Bangladesh. The raw data are based on five fishing trawlers, namely FT Agro Food 1, FT Agro Food 2 and FT Agro Food 3 FT JK 1 and FT JK 2. Each attribute is measured in one of the four evaluation grades: Poor, Average, Good and Excellent. The belief degrees of attributes for different ships are shown in Table 1.

Table 1. Assessment of basic attributes of different ships.

\begin{tabular}{|c|c|c|c|c|c|}
\hline Criteria & FT Agro Food 1 & FT Agro Food 2 & FT Agro Food 3 & FT JK 1 & FT JK 2 \\
\hline Safety & $\begin{array}{l}\mathrm{P}(0.0), \mathrm{A}(0.9), \mathrm{G}(0.1), \mathrm{E}( \\
0.0)\end{array}$ & $\begin{array}{l}\mathrm{P}(0.0), \mathrm{A}(0.8), \mathrm{G}(0.2), \mathrm{E}( \\
0.0)\end{array}$ & $\begin{array}{l}\mathrm{P}(0.0), \mathrm{A}(0.0), \mathrm{G}(0.2), \mathrm{E}( \\
0.8)\end{array}$ & $\begin{array}{l}\mathrm{P}(0.0), \mathrm{A}(0.8), \mathrm{G}(0.0), \mathrm{E}( \\
0.2)\end{array}$ & $\begin{array}{l}\mathrm{P}(0.0), \mathrm{A}(0.0), \mathrm{G}(0.1), \mathrm{E}( \\
0.9)\end{array}$ \\
\hline Fire protection & $\begin{array}{l}\mathrm{P}(0.3), \mathrm{A}(0.5), \mathrm{G}(0.2), \mathrm{E}( \\
0.0)\end{array}$ & $\begin{array}{l}\mathrm{P}(0.2), \mathrm{A}(0.3), \mathrm{G}(0.5), \mathrm{E}( \\
0.0)\end{array}$ & $\begin{array}{l}\mathrm{P}(0.2), \mathrm{A}(0.4), \mathrm{G}(0.4), \mathrm{E}( \\
0.0)\end{array}$ & $\begin{array}{l}\mathrm{P}(0.0), \mathrm{A}(0.0), \mathrm{G}(1.0), \mathrm{E}( \\
0.0)\end{array}$ & $\begin{array}{l}\mathrm{P}(0.0), \mathrm{A}(1.0), \mathrm{G}(0.0), \mathrm{E}( \\
0.0)\end{array}$ \\
\hline Seaworthiness & $\begin{array}{l}\mathrm{P}(0.0), \mathrm{A}(0.0), \mathrm{G}(0.8), \mathrm{E}( \\
0.2)\end{array}$ & $\begin{array}{l}\mathrm{P}(0.1), \mathrm{A}(0.9), \mathrm{G}(0.0), \mathrm{E}( \\
0.0)\end{array}$ & $\begin{array}{l}\mathrm{P}(0.0), \mathrm{A}(0.0), \mathrm{G}(1.0), \mathrm{E}( \\
0.0)\end{array}$ & $\begin{array}{l}\mathrm{P}(0.2), \mathrm{A}(0.8), \mathrm{G}(0.0), \mathrm{E}( \\
0.0)\end{array}$ & $\begin{array}{l}\mathrm{P}(0.0), \mathrm{A}(0.0), \mathrm{G}(1.0), \mathrm{E}( \\
0.0)\end{array}$ \\
\hline Living facilities & $\begin{array}{l}\mathrm{P}(0.0), \mathrm{A}(0.2), \mathrm{G}(0.7), \mathrm{E}( \\
0.1)\end{array}$ & $\begin{array}{l}\mathrm{P}(0.0), \mathrm{A}(0.0), \mathrm{G}(0.8), \mathrm{E}( \\
0.2)\end{array}$ & $\begin{array}{l}\mathrm{P}(0.0), \mathrm{A}(0.0), \mathrm{G}(1.0), \mathrm{E}( \\
0.0)\end{array}$ & $\begin{array}{l}\mathrm{P}(0.0), \mathrm{A}(0.5), \mathrm{G}(0.5), \mathrm{E}( \\
0.0)\end{array}$ & $\begin{array}{l}\mathrm{P}(0.0), \mathrm{A}(0.0), \mathrm{G}(8.0), \mathrm{E}( \\
0.2)\end{array}$ \\
\hline Cargo systems & $\begin{array}{l}\mathrm{P}(0.0), \mathrm{A}(0.3), \mathrm{G}(0.5), \mathrm{E}( \\
0.2)\end{array}$ & $\begin{array}{l}\mathrm{P}(0.0), \mathrm{A}(0.3), \mathrm{G}(0.2), \mathrm{E}( \\
0.5)\end{array}$ & $\begin{array}{l}\mathrm{P}(0.0), \mathrm{A}(0.3), \mathrm{G}(0.6), \mathrm{E}( \\
0.1)\end{array}$ & $\begin{array}{l}\mathrm{P}(0.0), \mathrm{A}(0.4), \mathrm{G}(0.6), \mathrm{E}( \\
0.0)\end{array}$ & $\begin{array}{l}\mathrm{P}(0.0), \mathrm{A}(0.5), \mathrm{G}(0.5), \mathrm{E}( \\
0.0)\end{array}$ \\
\hline Anchor facilities & $\begin{array}{l}\mathrm{P}(0.0), \mathrm{A}(0.0), \mathrm{G}(0.2), \mathrm{E}( \\
0.8)\end{array}$ & $\begin{array}{l}\mathrm{P}(0.0), \mathrm{A}(0.0), \mathrm{G}(0.1), \mathrm{E}( \\
0.9)\end{array}$ & $\begin{array}{l}\mathrm{P}(0.0), \mathrm{A}(0.0), \mathrm{G}(0.5), \mathrm{E}( \\
0.5)\end{array}$ & $\begin{array}{l}\mathrm{P}(0.0), \mathrm{A}(0.0), \mathrm{G}(0.3), \mathrm{E}( \\
0.7)\end{array}$ & $\begin{array}{l}\mathrm{P}(0.0), \mathrm{A}(0.0), \mathrm{G}(0.1), \mathrm{E}( \\
0.9)\end{array}$ \\
\hline Communication & $\begin{array}{l}\mathrm{P}(0.0), \mathrm{A}(0.0), \mathrm{G}(1.0), \mathrm{E}( \\
0.0)\end{array}$ & $\begin{array}{l}\mathrm{P}(0.0), \mathrm{A}(0.0), \mathrm{G}(0.0), \mathrm{E}( \\
1.0)\end{array}$ & $\begin{array}{l}\mathrm{P}(0.2), \mathrm{A}(0.8), \mathrm{G}(0.0), \mathrm{E}( \\
0.0)\end{array}$ & $\begin{array}{l}\mathrm{P}(0.0), \mathrm{A}(1.0), \mathrm{G}(0.0), \mathrm{E}( \\
0.0)\end{array}$ & $\begin{array}{l}\mathrm{P}(0.0), \mathrm{A}(0.0), \mathrm{G}(1.0), \mathrm{E}( \\
0.0)\end{array}$ \\
\hline Above waterline & $\begin{array}{l}\mathrm{P}(0.2), \mathrm{A}(0.8), \mathrm{G}(0.0), \mathrm{E}( \\
0.0)\end{array}$ & $\begin{array}{l}\mathrm{P}(0.3), \mathrm{A}(0.7), \mathrm{G}(0.0), \mathrm{E}( \\
0.0)\end{array}$ & $\begin{array}{l}\mathrm{P}(0.2), \mathrm{A}(0.8), \mathrm{G}(0.0), \mathrm{E}( \\
0.0)\end{array}$ & $\begin{array}{l}\mathrm{P}(0.6), \mathrm{A}(0.4), \mathrm{G}(0.0), \mathrm{E}( \\
0.0)\end{array}$ & $\begin{array}{l}\mathrm{P}(0.2), \mathrm{A}(0.8), \mathrm{G}(0.0), \mathrm{E}( \\
0.0)\end{array}$ \\
\hline Under waterline & $\begin{array}{l}\mathrm{P}(0.0), \mathrm{A}(0.0), \mathrm{G}(0.2), \mathrm{E}( \\
0.8)\end{array}$ & $\begin{array}{l}\mathrm{P}(0.0), \mathrm{A}(0.7), \mathrm{G}(0.3), \mathrm{E}( \\
0.0)\end{array}$ & $\begin{array}{l}\mathrm{P}(0.0), \mathrm{A}(0.1), \mathrm{G}(0.9), \mathrm{E}( \\
0.0)\end{array}$ & $\begin{array}{l}\mathrm{P}(0.0), \mathrm{A}(0.0), \mathrm{G}(0.0), \mathrm{E}( \\
1.0)\end{array}$ & $\begin{array}{l}\mathrm{P}(0.0), \mathrm{A}(0.1), \mathrm{G}(0.9), \mathrm{E}( \\
0.0)\end{array}$ \\
\hline Internal arrangement & $\begin{array}{l}\mathrm{P}(0.0), \mathrm{A}(0.0), \mathrm{G}(0.9), \mathrm{E}( \\
0.1)\end{array}$ & $\begin{array}{l}\mathrm{P}(0.0), \mathrm{A}(0.0), \mathrm{G}(1.0), \mathrm{E}( \\
0.0)\end{array}$ & $\begin{array}{l}\mathrm{P}(0.0), \mathrm{A}(0.0), \mathrm{G}(0.1), \mathrm{E}( \\
0.9)\end{array}$ & $\begin{array}{l}\mathrm{P}(0.0), \mathrm{A}(0.5), \mathrm{G}(0.5), \mathrm{E}( \\
0.0)\end{array}$ & $\begin{array}{l}\mathrm{P}(0.0), \mathrm{A}(0.0), \mathrm{G}(0.1), \mathrm{E}( \\
0.9)\end{array}$ \\
\hline Engine room & $\begin{array}{l}\mathrm{P}(0.3), \mathrm{A}(0.7), \mathrm{G}(0.0), \mathrm{E}( \\
0.0)\end{array}$ & $\begin{array}{l}\mathrm{P}(0.2), \mathrm{A}(0.8), \mathrm{G}(0.0), \mathrm{E}( \\
0.0)\end{array}$ & $\begin{array}{l}\mathrm{P}(0.1), \mathrm{A}(0.9), \mathrm{G}(0.0), \mathrm{E}( \\
0.0)\end{array}$ & $\begin{array}{l}\mathrm{P}(1.0), \mathrm{A}(0.0), \mathrm{G}(0.0), \mathrm{E}( \\
0.0)\end{array}$ & $\begin{array}{l}\mathrm{P}(0.2), \mathrm{A}(0.8), \mathrm{G}(0.0), \mathrm{E}( \\
0.0)\end{array}$ \\
\hline Navigation & $\begin{array}{l}\mathrm{P}(0.1), \mathrm{A}(0.9), \mathrm{G}(0.0), \mathrm{E}( \\
0.0)\end{array}$ & $\begin{array}{l}\mathrm{P}(0.0), \mathrm{A}(1.0), \mathrm{G}(0.0), \mathrm{E}( \\
0.0)\end{array}$ & $\begin{array}{l}\mathrm{P}(0.0), \mathrm{A}(0.0), \mathrm{G}(1.0), \mathrm{E}( \\
0.0)\end{array}$ & $\begin{array}{l}\mathrm{P}(0.0), \mathrm{A}(0.0), \mathrm{G}(0.0), \mathrm{E}( \\
1.0)\end{array}$ & $\begin{array}{l}\mathrm{P}(0.0), \mathrm{A}(0.0), \mathrm{G}(1.0), \mathrm{E}( \\
0.0)\end{array}$ \\
\hline Cargo monitor & $\begin{array}{l}\mathrm{P}(0.0), \mathrm{A}(0.0), \mathrm{G}(0.2), \mathrm{E}( \\
0.8)\end{array}$ & $\begin{array}{l}\mathrm{P}(0.0), \mathrm{A}(0.0), \mathrm{G}(0.0), \mathrm{E}( \\
1.0)\end{array}$ & $\begin{array}{l}\mathrm{P}(0.0), \mathrm{A}(0.0), \mathrm{G}(0.1), \mathrm{E}( \\
0.9)\end{array}$ & $\begin{array}{l}\mathrm{P}(0.0), \mathrm{A}(0.0), \mathrm{G}(1.0), \mathrm{E}( \\
0.0)\end{array}$ & $\begin{array}{l}\mathrm{P}(0.0), \mathrm{A}(0.0), \mathrm{G}(0.1), \mathrm{E}( \\
0.9)\end{array}$ \\
\hline Net Present Value & 1620 & 4635 & 6810 & 4250 & 6805 \\
\hline Required Freight Rate & 14.7 & 13.8 & 13.8 & 12.5 & 12.6 \\
\hline
\end{tabular}

Here, $\mathrm{P}=$ Poor, $\mathrm{A}=$ Average, $\mathrm{G}=\mathrm{Good}$ and $\mathrm{E}=$ Excellent.

\subsection{Transformation of the Quantitative Attributes}

In the ER approach, the quantitative attributes are converted into its equivalent qualitative attributes using a common set of evaluation grades in the format of belief structures [4].After then, all qualitative attributes are aggregated for assessment. For doing this, a set of best and worst values for each quantitative attribute needs to be identified, then the best value is considered as highest evaluation grade and the lowest value is considered as the lowest evaluation grade. For example, in Table 1, the value of NPV, 1000 is equivalent to Poor and 7000 is equivalent to Excellent. The values equivalent to Average and Good are calculated based on the two equal intervals in between Poor and Excellent. For example, the values equivalent to Average and Good are 3000 and 5000, respectively. Quantitative attributes are converted to their equivalent qualitative attributes using equation-21. For example, Net Present Value and Required Freight Rate are found for the ship FT Agro Food 1 are $(\operatorname{Poor}(0.8)$, Average(0.2)) and $(\operatorname{Good}(0.3)$, Excellent(0.7)), respectively. All the quantitative values of each alternative are converted in the same way. Using the above belief degrees for attributes of all alternative ships is shown in Table 2. 
Table 2. Assessment of Bottom Level Attributes at each option.

\begin{tabular}{|c|c|c|c|c|c|}
\hline Level 3 & FT Agro Food 1 & FT Agro Food 2 & FT Agro Food 3 & FT JK 1 & FT JK 2 \\
\hline Safety & $\begin{array}{l}\mathrm{P}(0.0), \mathrm{A}(0.9), \mathrm{G}(0.1), \mathrm{E}(0 \\
.0)\end{array}$ & $\begin{array}{l}\mathrm{P}(0.0), \mathrm{A}(0.8), \mathrm{G}(0.2), \mathrm{E}(0 \\
.0)\end{array}$ & $\begin{array}{l}\mathrm{P}(0.0), \mathrm{A}(0.0), \mathrm{G}(0.2), \mathrm{E}(0 \\
.8)\end{array}$ & $\begin{array}{l}\mathrm{P}(0.0), \mathrm{A}(0.8), \mathrm{G}(0.0), \mathrm{E}(0 \\
.2)\end{array}$ & $\begin{array}{l}\mathrm{P}(0.0), \mathrm{A}(0.0), \mathrm{G}(0.1), \mathrm{E}(0 \\
.9)\end{array}$ \\
\hline Fire protection & $\begin{array}{l}\mathrm{P}(0.3), \mathrm{A}(0.5), \mathrm{G}(0.2), \mathrm{E}(0 \\
.0)\end{array}$ & $\begin{array}{l}\mathrm{P}(0.2), \mathrm{A}(0.3), \mathrm{G}(0.5), \mathrm{E}(0 \\
.0)\end{array}$ & $\begin{array}{l}\mathrm{P}(0.2), \mathrm{A}(0.4), \mathrm{G}(0.4), \mathrm{E}(0 \\
.0)\end{array}$ & $\begin{array}{l}\mathrm{P}(0.0), \mathrm{A}(0.0), \mathrm{G}(1.0), \mathrm{E}(0 \\
.0)\end{array}$ & $\begin{array}{l}\mathrm{P}(0.0), \mathrm{A}(1.0), \mathrm{G}(0.0), \mathrm{E}(0 \\
.0)\end{array}$ \\
\hline Seaworthiness & $\begin{array}{l}\mathrm{P}(0.0), \mathrm{A}(0.0), \mathrm{G}(0.8), \mathrm{E}(0 \\
.2)\end{array}$ & $\begin{array}{l}\mathrm{P}(0.1), \mathrm{A}(0.9), \mathrm{G}(0.0), \mathrm{E}(0 \\
.0)\end{array}$ & $\begin{array}{l}\mathrm{P}(0.0), \mathrm{A}(0.0), \mathrm{G}(1.0), \mathrm{E}(0 \\
.0)\end{array}$ & $\begin{array}{l}\mathrm{P}(0.2), \mathrm{A}(0.8), \mathrm{G}(0.0), \mathrm{E}(0 \\
.0)\end{array}$ & $\begin{array}{l}\mathrm{P}(0.0), \mathrm{A}(0.0), \mathrm{G}(1.0), \mathrm{E}(0 \\
.0)\end{array}$ \\
\hline Living facilities & $\begin{array}{l}\mathrm{P}(0.0), \mathrm{A}(0.2), \mathrm{G}(0.7), \mathrm{E}(0 \\
.1)\end{array}$ & $\begin{array}{l}\mathrm{P}(0.0), \mathrm{A}(0.0), \mathrm{G}(0.8), \mathrm{E}(0 \\
.2)\end{array}$ & $\begin{array}{l}\mathrm{P}(0.0), \mathrm{A}(0.0), \mathrm{G}(1.0), \mathrm{E}(0 \\
.0)\end{array}$ & $\begin{array}{l}\mathrm{P}(0.0), \mathrm{A}(0.5), \mathrm{G}(0.5), \mathrm{E}(0 \\
.0)\end{array}$ & $\begin{array}{l}\mathrm{P}(0.0), \mathrm{A}(0.0), \mathrm{G}(8.0), \mathrm{E}(0 \\
.2)\end{array}$ \\
\hline Cargo systems & $\begin{array}{l}\mathrm{P}(0.0), \mathrm{A}(0.3), \mathrm{G}(0.5), \mathrm{E}(0 \\
.2)\end{array}$ & $\begin{array}{l}\mathrm{P}(0.0), \mathrm{A}(0.3), \mathrm{G}(0.2), \mathrm{E}(0 \\
.5)\end{array}$ & $\begin{array}{l}\mathrm{P}(0.0), \mathrm{A}(0.3), \mathrm{G}(0.6), \mathrm{E}(0 \\
.1)\end{array}$ & $\begin{array}{l}\mathrm{P}(0.0), \mathrm{A}(0.4), \mathrm{G}(0.6), \mathrm{E}(0 \\
.0)\end{array}$ & $\begin{array}{l}\mathrm{P}(0.0), \mathrm{A}(0.5), \mathrm{G}(0.5), \mathrm{E}(0 \\
.0)\end{array}$ \\
\hline Anchor facilities & $\begin{array}{l}\mathrm{P}(0.0), \mathrm{A}(0.0), \mathrm{G}(0.2), \mathrm{E}(0 \\
.8)\end{array}$ & $\begin{array}{l}\mathrm{P}(0.0), \mathrm{A}(0.0), \mathrm{G}(0.1), \mathrm{E}(0 \\
.9)\end{array}$ & $\begin{array}{l}\mathrm{P}(0.0), \mathrm{A}(0.0), \mathrm{G}(0.5), \mathrm{E}(0 \\
.5)\end{array}$ & $\begin{array}{l}\mathrm{P}(0.0), \mathrm{A}(0.0), \mathrm{G}(0.3), \mathrm{E}(0 \\
.7)\end{array}$ & $\begin{array}{l}\mathrm{P}(0.0), \mathrm{A}(0.0), \mathrm{G}(0.1), \mathrm{E}(0 \\
.9)\end{array}$ \\
\hline Communication & $\begin{array}{l}\mathrm{P}(0.0), \mathrm{A}(0.0), \mathrm{G}(1.0), \mathrm{E}(0 \\
.0)\end{array}$ & $\begin{array}{l}\mathrm{P}(0.0), \mathrm{A}(0.0), \mathrm{G}(0.0), \mathrm{E}(1 \\
.0)\end{array}$ & $\begin{array}{l}\mathrm{P}(0.2), \mathrm{A}(0.8), \mathrm{G}(0.0), \mathrm{E}(0 \\
.0)\end{array}$ & $\begin{array}{l}\mathrm{P}(0.0), \mathrm{A}(1.0), \mathrm{G}(0.0), \mathrm{E}(0 \\
.0)\end{array}$ & $\begin{array}{l}\mathrm{P}(0.0), \mathrm{A}(0.0), \mathrm{G}(1.0), \mathrm{E}(0 \\
.0)\end{array}$ \\
\hline Above waterline & $\begin{array}{l}\mathrm{P}(0.2), \mathrm{A}(0.8), \mathrm{G}(0.0), \mathrm{E}(0 \\
.0)\end{array}$ & $\begin{array}{l}\mathrm{P}(0.3), \mathrm{A}(0.7), \mathrm{G}(0.0), \mathrm{E}(0 \\
.0)\end{array}$ & $\begin{array}{l}\mathrm{P}(0.2), \mathrm{A}(0.8), \mathrm{G}(0.0), \mathrm{E}(0 \\
.0)\end{array}$ & $\begin{array}{l}\mathrm{P}(0.6), \mathrm{A}(0.4), \mathrm{G}(0.0), \mathrm{E}(0 \\
.0)\end{array}$ & $\begin{array}{l}\mathrm{P}(0.2), \mathrm{A}(0.8), \mathrm{G}(0.0), \mathrm{E}(0 \\
.0)\end{array}$ \\
\hline Under waterline & $\begin{array}{l}\mathrm{P}(0.0), \mathrm{A}(0.0), \mathrm{G}(0.2), \mathrm{E}(0 \\
.8)\end{array}$ & $\begin{array}{l}\mathrm{P}(0.0), \mathrm{A}(0.7), \mathrm{G}(0.3), \mathrm{E}(0 \\
.0)\end{array}$ & $\begin{array}{l}\mathrm{P}(0.0), \mathrm{A}(0.1), \mathrm{G}(0.9), \mathrm{E}(0 \\
.0)\end{array}$ & $\begin{array}{l}\mathrm{P}(0.0), \mathrm{A}(0.0), \mathrm{G}(0.0), \mathrm{E}(1 \\
.0)\end{array}$ & $\begin{array}{l}\mathrm{P}(0.0), \mathrm{A}(0.1), \mathrm{G}(0.9), \mathrm{E}(0 \\
.0)\end{array}$ \\
\hline Internal arrangement & $\begin{array}{l}\mathrm{P}(0.0), \mathrm{A}(0.0), \mathrm{G}(0.9), \mathrm{E}(0 \\
.1)\end{array}$ & $\begin{array}{l}\mathrm{P}(0.0), \mathrm{A}(0.0), \mathrm{G}(1.0), \mathrm{E}(0 \\
.0)\end{array}$ & $\begin{array}{l}\mathrm{P}(0.0), \mathrm{A}(0.0), \mathrm{G}(0.1), \mathrm{E}(0 \\
.9)\end{array}$ & $\begin{array}{l}\mathrm{P}(0.0), \mathrm{A}(0.5), \mathrm{G}(0.5), \mathrm{E}(0 \\
.0)\end{array}$ & $\begin{array}{l}\mathrm{P}(0.0), \mathrm{A}(0.0), \mathrm{G}(0.1), \mathrm{E}(0 \\
.9)\end{array}$ \\
\hline Engine room & $\begin{array}{l}\mathrm{P}(0.3), \mathrm{A}(0.7), \mathrm{G}(0.0), \mathrm{E}(0 \\
.0)\end{array}$ & $\begin{array}{l}\mathrm{P}(0.2), \mathrm{A}(0.8), \mathrm{G}(0.0), \mathrm{E}(0 \\
.0)\end{array}$ & $\begin{array}{l}\mathrm{P}(0.1), \mathrm{A}(0.9), \mathrm{G}(0.0), \mathrm{E}(0 \\
.0)\end{array}$ & $\begin{array}{l}\mathrm{P}(1.0), \mathrm{A}(0.0), \mathrm{G}(0.0), \mathrm{E}(0 \\
.0)\end{array}$ & $\begin{array}{l}\mathrm{P}(0.2), \mathrm{A}(0.8), \mathrm{G}(0.0), \mathrm{E}(0 \\
.0)\end{array}$ \\
\hline Navigation & $\begin{array}{l}\mathrm{P}(0.1), \mathrm{A}(0.9), \mathrm{G}(0.0), \mathrm{E}(0 \\
.0)\end{array}$ & $\begin{array}{l}\mathrm{P}(0.0), \mathrm{A}(1.0), \mathrm{G}(0.0), \mathrm{E}(0 \\
.0)\end{array}$ & $\begin{array}{l}\mathrm{P}(0.0), \mathrm{A}(0.0), \mathrm{G}(1.0), \mathrm{E}(0 \\
.0)\end{array}$ & $\begin{array}{l}\mathrm{P}(0.0), \mathrm{A}(0.0), \mathrm{G}(0.0), \mathrm{E}(1 \\
.0)\end{array}$ & $\begin{array}{l}\mathrm{P}(0.0), \mathrm{A}(0.0), \mathrm{G}(1.0), \mathrm{E}(0 \\
.0)\end{array}$ \\
\hline Cargo monitor & $\begin{array}{l}\mathrm{P}(0.0), \mathrm{A}(0.0), \mathrm{G}(0.2), \mathrm{E}(0 \\
.8)\end{array}$ & $\begin{array}{l}\mathrm{P}(0.0), \mathrm{A}(0.0), \mathrm{G}(0.0), \mathrm{E}(1 \\
.0)\end{array}$ & $\begin{array}{l}\mathrm{P}(0.0), \mathrm{A}(0.0), \mathrm{G}(0.1), \mathrm{E}(0 \\
.9)\end{array}$ & $\begin{array}{l}\mathrm{P}(0.0), \mathrm{A}(0.0), \mathrm{G}(1.0), \mathrm{E}(0 \\
.0)\end{array}$ & $\begin{array}{l}\mathrm{P}(0.0), \mathrm{A}(0.0), \mathrm{G}(0.1), \mathrm{E}(0 \\
.9)\end{array}$ \\
\hline Net Present Value & $\begin{array}{l}\mathrm{P}(0.8), \mathrm{A}(0.2), \mathrm{G}(0.0), \mathrm{E}(0 \\
.0)\end{array}$ & $\begin{array}{l}\mathrm{P}(0.0), \mathrm{A}(0.2), \mathrm{G}(0.8), \mathrm{E}(0 \\
.0)\end{array}$ & $\begin{array}{l}\mathrm{P}(0.0), \mathrm{A}(0.0), \mathrm{G}(0.9), \mathrm{E}(0 \\
.1)\end{array}$ & $\begin{array}{l}\mathrm{P}(0.0), \mathrm{A}(0.6), \mathrm{G}(0.4), \mathrm{E}(0 \\
.0)\end{array}$ & $\begin{array}{l}\mathrm{P}(0.0), \mathrm{A}(0.0), \mathrm{G}(0.9), \mathrm{E}(0 \\
.1)\end{array}$ \\
\hline Required Freight Rate & $\begin{array}{l}\mathrm{P}(0.0), \mathrm{A}(0.0), \mathrm{G}(0.3), \mathrm{E}(0 \\
.7)\end{array}$ & $\begin{array}{l}\mathrm{P}(0.0), \mathrm{A}(0.8), \mathrm{G}(0.2), \mathrm{E}(0 \\
.0)\end{array}$ & $\begin{array}{l}\mathrm{P}(0.0), \mathrm{A}(0.8), \mathrm{G}(0.2), \mathrm{E}(0 \\
.0)\end{array}$ & $\begin{array}{l}\mathrm{P}(0.5), \mathrm{A}(0.5), \mathrm{G}(0.0), \mathrm{E}(0 \\
.0)\end{array}$ & $\begin{array}{l}\mathrm{P}(0.6), \mathrm{A}(0.4), \mathrm{G}(0.0), \mathrm{E}(0 \\
.0)\end{array}$ \\
\hline
\end{tabular}

Table 3. Obtained assessments for evaluation of level 2 attributes.

\begin{tabular}{|c|c|c|c|c|c|}
\hline Level 2 & FT Agro Food 1 & Food 2 & ro Food 3 & FT JK 1 & FT JK 2 \\
\hline Performance & $\begin{array}{l}\text { 4927), } \mathrm{G}(0 . \\
8)\end{array}$ & 6620), $\mathrm{G}(0$ & 1562), $\mathrm{G}(0$ & $\begin{array}{l}(0.4894), \mathrm{G}(0 . \\
522)\end{array}$ & $\begin{array}{l}\mathrm{P}(0.0000) \\
3176), \mathrm{E}(0\end{array}$ \\
\hline Equipment & $\begin{array}{l}\mathrm{P}(0.0000), \mathrm{A}(0.1073), \mathrm{G}(0 . \\
6476), \mathrm{E}(0.2452)\end{array}$ & $\begin{array}{l}\mathrm{P}(0.0000), \mathrm{A}(0.0605), \mathrm{G}(0 . \\
2396), \mathrm{E}(0.6999)\end{array}$ & $\begin{array}{l}\mathrm{P}(0.0435), \mathrm{A}(0.2567), \mathrm{G}(0 . \\
5656), \mathrm{E}(0.1342)\end{array}$ & $\begin{array}{l}\mathrm{P}(0.000), \mathrm{A}(0.4966), \mathrm{G}(0.3 \\
515), \mathrm{E}(0.1519)\end{array}$ & $\begin{array}{l}\mathrm{P}(0.0000), \mathrm{A}(0.1049), \mathrm{G}(0 . \\
6519), \mathrm{E}(0.2433)\end{array}$ \\
\hline Appearance & $\begin{array}{l}\mathrm{P}(0.0536), \mathrm{A}(0.2145), \mathrm{G}(0 . \\
4613), \mathrm{E}(0.2706)\end{array}$ & $\begin{array}{l}\mathrm{P}(0.0757), \mathrm{A}(0.4060), \mathrm{G}(0 . \\
5184), \mathrm{E}(0.0000)\end{array}$ & $\begin{array}{l}0.2560), \mathrm{G}(0 . \\
36)\end{array}$ & $\begin{array}{l}\mathrm{P}(0.1627), \mathrm{A}(0.3554), \mathrm{G}(0 . \\
2108), \mathrm{E}(0.2711)\end{array}$ & $.2560), \mathrm{G}(0$ \\
\hline Automation & $\begin{array}{l}\mathrm{P}(0.1190), \mathrm{A}(0.6307), \mathrm{G}(0 . \\
0501), \mathrm{E}(0.2002)\end{array}$ & $\begin{array}{l}\mathrm{P}(0.0490), \mathrm{A}(0.7065), \mathrm{G}(0 . \\
0000), \mathrm{E}(0.2446)\end{array}$ & $\begin{array}{l}\mathrm{A}(0.2485), \mathrm{G}(0 . \\
485)\end{array}$ & $\begin{array}{l}(0.0000), \mathrm{G}(0 . \\
375)\end{array}$ & $\begin{array}{l}\mathrm{P}(0.0552), \\
4755), \mathrm{E}(0\end{array}$ \\
\hline Economy & $\begin{array}{l}\mathrm{P}(0.5538), \mathrm{A}(0.1385), \mathrm{G}(0 . \\
0923), \mathrm{E}(0.2154)\end{array}$ & $\begin{array}{l}\mathrm{P}(0.0000), \mathrm{A}(0.3995), \mathrm{G}(0 . \\
6005), \mathrm{E}(0.0000)\end{array}$ & $\begin{array}{l}\mathrm{P}(0.0000), \mathrm{A}(0.2273), \mathrm{G}(0 . \\
7088), \mathrm{E}(0.0639)\end{array}$ & $\begin{array}{l}\mathrm{P}(0.1351), \mathrm{A}(0.6216), \mathrm{G}(0 . \\
2432), \mathrm{E}(0.0000)\end{array}$ & $\begin{array}{l}\mathrm{P}(0.1846), \mathrm{A}(0.1231), \mathrm{G}(0 . \\
6231), \mathrm{E}(0.0692)\end{array}$ \\
\hline
\end{tabular}

Table 4. Overall evaluation of alternative ships.

\begin{tabular}{lllll}
\hline Alternatives & FT Agro Food 1 & FT Agro Food 2 & FT Agro Food 3 & FT JK 1 \\
\hline \multirow{2}{*}{ Evaluation } & $\mathrm{P}(0.2955), \mathrm{A}(0.2965), \mathrm{G}(0$. & $\mathrm{P}(0.0334), \mathrm{A}(0.5013), \mathrm{G}(0$. & $\mathrm{P}(0.0277), \mathrm{A}(0.1938), \mathrm{G}(0$. & $\mathrm{P}(0.1021), \mathrm{A}(0.5262), \mathrm{G}(0$. \\
& $2407), \mathrm{E}(0.1673)$ & $4018), \mathrm{P}(0.0635)$ & $6448), \mathrm{E}(0.1336)$ & $2979), \mathrm{E}(0.0738)$ \\
\hline
\end{tabular}

\subsection{Expected Average Utility of Alternatives}

After getting the overall assessment of five different alternative ships, the average utilities [29] of all alternatives are calculated for ranking among them. The evaluation grade's utilities are considered to be as follows:

$\mathrm{U}($ Poor $)=0.2, \mathrm{U}($ Average $)=0.4, \mathrm{U}(\mathrm{Good})=0.8, \mathrm{U}$ $($ Excellent $)=1.0$

The total expected utilities of five ships as follow:

$\mathrm{U}($ FT Agro Food 1$)=$
$0.2 * 0.2955+0.4 * 0.2965+0.8 * 0.2407+1.0 * 0.1673=0.5376$

$\mathrm{U}($ FT Agro Food 2$)=$

$0.2 * 0.0334+0.4 * 0.5013+0.8 * 0.4018+1.0 * 0.0635=0.5922$

$\mathrm{U}($ FT Agro Food 3$)=$

$0.2 * 0.0277+0.4 * 0.1938+0.8 * 0.6448+1.0 * 0.1336=0.7325$

$\mathrm{U}(\mathrm{FT} \mathrm{JK} 1)=$

$0.2 * 0.1021+0.4 * 0.5262+0.8 * 0.2979+1.0 * 0.0738=0.5430$

$\mathrm{U}(\mathrm{FT} \mathrm{JK} 2)=$

$0.2 * 0.0826+0.4 * 0.2217+0.8 * 0.5298+1.0 * 0.1658=0.6948$ 


\subsection{Final Results}

are shown in Table 5.

Final results and ranking among the five alternative ships

Table 5. Final results.

\begin{tabular}{llllll}
\hline Alternatives & FT Agro Food 1 & FT Agro Food 2 & FT Agro Food 3 & FT JK 1 & FT JK 2 \\
\hline Expected Utilities & 0.5376 & 0.5921 & 0.7325 & 0.5430 & 0.6948 \\
Ranking & 5 & 3 & 1 & 4 & 2 \\
\hline
\end{tabular}

\section{Conclusion}

Ship assessment is a very important problem around the world. In ship assessment, the traditional methods mainly uses economic data that are linear in nature, hence, the methods are not sufficient to deal uncertainties and nonlinear information. So, ER approach is the most appropriate technique that can handle uncertainty and nonlinear information.

ER approach based algorithm is implemented and evaluated in this research. Five fishing trawlers, namely, FT Agro Food 1, FT Agro Food 2 and FT Agro Food 3 FT JK 1 and FT JK 2 from Western Fishers Shipyard Ltd has been considered in experiment. The five main factors such as Performance, Equipment, Appearance, Automation and Economy are focused in the assessment of ships. In this research, it is concluded that the performance of FT Agro Food 3 is the highest among all other ships and have the highest ranking. In the case of particular ship assessment process the relative gravity of each feature is also measured by identifying the strengths and weaknesses of its own on every single ship. This research presents the result of an individual ship in the form of interval from minimum utility to maximum utility in a systematic and effective way. Only 15 attributes are considered in this experiment, further works could be carried out with considering a large number of uncertain and risky attributes to generate a robust and efficient result. It is strongly recommended to use ER approach based algorithm in ship industry because it can handle both qualitative and quantitative attributes and provide robust and accurate result to minimize risk and uncertainty.

\section{References}

[1] I. L. Buxton, Engineering Economics and Ship Design, $2^{\text {nd }}$ edition, pp 57, 58.

[2] Hans Liwang, "Risk-based ship security analysis - an approach based on civilian and military methods," ISSN 1652-9189 Report No 12:141, 2012.

[3] Jian-Bo Yang and Dong-Ling $\mathrm{Xu}$, "Nonlinear Information Aggregation via Evidential Reasoning in Multi-attribute Decision Analysis Under Uncertainty," IEEE Transactions on systems, Man, Cybernetics- Part A: system and humans, vol. 32, no. 3, May 2002.,

[4] Xinlian Xie, Dong-Ling Xu, Jian-Bo Yang, Jin Wang, Jun Ren, Shijun Yu, " Ship selection using a multiple-criteria synthesis approach,” J Mar Sci Technol (2008) 13:50-62.
[5] I. Bogardi and A. Baedossy, "Application of MADM to geological exploration," in Essays and Surveys on Multiple Criteria Decision Making, P. Hansen, Ed. New York: Springer-Verlag, 1983.

[6] J. B. Yang and M. G. Singh, "An evidential reasoning approach for multiple attribute decision making with uncertainty," IEEE Trans, Syst.,Man, Cypern., vol. 24, no. 1, pp, 1-18, 1994.

[7] G. Balestra and A. Tsoukias, "Multicriteria analysis represented by artificial intelligence techniques," J. Oper. Res. Soc., vol. 41, no. 5, pp.419-430, 1990.

[8] B. G. Buchanan and E. H. Shortliffe, Rule-Based Expert Systems. Reading, MA: Addison Wesley, 1984.

[9] A. Bufardi, "On the construction of fuzzy preference structures," J. Multi-Criteria Decision Analysis, vol. 7, no. 3, pp. $57-88,1998$

[10] C. H. Cheng and D. L. Mon, "Evaluating weapon systems by analytical hierarchy process based on fuzzy scales," Fuzzy Sets Syst., vol. 63, no.1, pp. 1-10, 1994.

[11] R. L. Keeney and H. Raiffa, Decisions With Multiple Objectives, 2nded. Cambridge, U.K.: Cambridge Univ. Press, 1993

[12] C. C. White, "A survey on the integration of decision analysis and expert systems for decision support," IEEE Trans. Syst., Man, Cybern., vol. 20, no. 2, pp. 358-364, 1990.

[13] R. R. Yager, "On the Dempster-Shafer framework and new combination rules," Inf. Sci., vol. 41, no. 2, pp. 93-137, 1987.

[14] R. R. Yager, "Decision-making under various types of uncertainties," J. Intell. Fuzzy Syst., vol. 3, no. 4, pp. 317-323, 1995.

[15] J. Yen, "Generalizing the Dempster-Shafer theory to fuzzy Sets," IEEE Trans. Syst., Man, Cybern., vol. 20, no. 3, pp. $559-570,1990$.

[16] H. J. Zimmermann, "Problems and tools to model uncertainty in expert and decision support systems," Math. Comput. Model., vol. 14, pp. 8-20,1990.

[17] J. B. Yang and D. L. Xu, "On the evidential reasoning algorithm for multiattribute decision analysis with uncertainty," IEEE Trans. Syst., Man, Cybern. A, vol. 32, pp. 289-304, May 2002.

[18] J. B. Yang and P. Sen, "A general multilevel evaluation process for hybrid MADM with uncertainty," IEEE Trans. Syst., Man, Cybern., vol.24, pp. 1458-1473, 1994.

[19] J. B. Yang, "Rule and utility-based evidential reasoning approach for complex decision analysis," Eur. J. Oper. Res., vol. 131, no. 1, pp. 31-61, 2001. 
[20] Lotfi A. Zadeh, A Simple View of the Dempster-Shafer Theory of Evidence and its Implication for the Rule of Combination, AI Magazine Volume 7 Number 2 (1986) (C) AAAI).

[21] R. Lopez de Mantaras, Approximate Reasoning Models. Chichester, U.K.: Ellis Horwood Ltd., 1990.

[22] J. L. Corner and C. W. Kirkwood, "The magnitude of errors in proximal multiattribute decision analysis with probabilistically dependent attributes," Manage. Sci., vol. 42, no. 7, pp. 1033-1042, 1996.

[23] C. W. Kirkwood, "Estimating the impact of uncertainty on a deterministic multiattribute evaluation," Manage. Sci., vol. 38, no. 6, p. $819,1992$.

[24] "An algebraic approach to formulating and solving large models for sequential decisions under uncertainty," Manage. Sci., vol. 39, no. 7, p. 900, 1993.

[25] T. L. Saaty, The Analytic Hierarchy Process. Pittsburgh, PA: Univ. Pittsburgh, 1988.
[26] J. Barzilai, "Deriving weights from pairwise comparison matrices," J. Oper. Res. Soc., vol. 48, pp. 1226-1232, 1997.

[27] G. Islei and A. G. Lockett, "Judgmental modeling based on geometric least square," Eur. J. Oper. Res., vol. 36, pp. 27-35, 1988.

[28] N. C. Proudlove, "The support of group decision making using judgmental modeling: An exploration of the contribution of behavioral factors," Ph.D. dissertation, Manchester Business School, Manchester, U.K., 1999.

[29] E. Jacquet-Lagreze and J. Siskos, “Assessing a set of additive utility functions for multicriteria decision making, the UTA method," Eur, J. Oper, Res., vol. 10, pp. 151-164, 1982.

[30] J. B. Yang and P. Sen, "Preference modeling by estimating local utility functions for multiobjective optimization," Eur. J. Oper. Res., vol. 95, pp. 115-138, 1996.

[31] Roger S. Pressman.(2005) Software engineering: a practitioners approach. - 6th ed. p. cm.- (McGraw-Hill series in computer science) Includes index. ISBN 0 -07365578-3, p373- 374. 